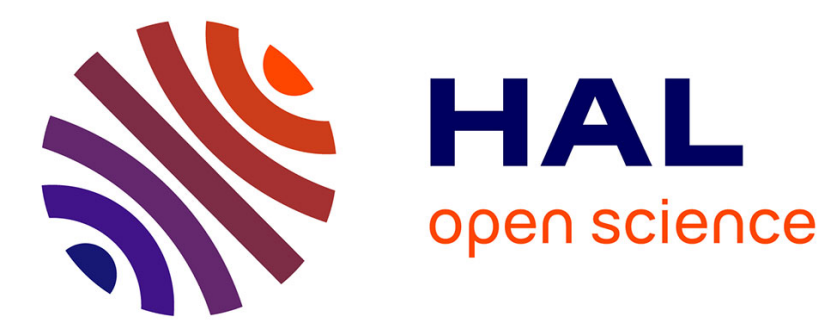

\title{
Internal erosion of chemically reinforced granular materials: a granulometric approach
}

Bogdan Muresan, Nadia Saiyouri, Achraf Guefrech, Pierre-Yves Hicher

\section{To cite this version:}

Bogdan Muresan, Nadia Saiyouri, Achraf Guefrech, Pierre-Yves Hicher. Internal erosion of chemically reinforced granular materials: a granulometric approach. Journal of Hydrology, 2011, 411 (3-4), pp.178-184. 10.1016/j.jhydrol.2011.09.009 . hal-00906983

\section{HAL Id: hal-00906983 https://hal.science/hal-00906983}

Submitted on 24 May 2017

HAL is a multi-disciplinary open access archive for the deposit and dissemination of scientific research documents, whether they are published or not. The documents may come from teaching and research institutions in France or abroad, or from public or private research centers.
L'archive ouverte pluridisciplinaire HAL, est destinée au dépôt et à la diffusion de documents scientifiques de niveau recherche, publiés ou non, émanant des établissements d'enseignement et de recherche français ou étrangers, des laboratoires publics ou privés. 


\title{
Internal erosion of chemically reinforced granular materials: A
}

\section{granulometric approach}

\author{
Bogdan Muresan Nadia Saiyouri, Achraf Guefrech, Pierre-Yves Hicher \\ Ecole Centrale de Nantes, GeM - Institut de Recherche en Génie Civil et Mécanique - UMR CNRS 6183, 1 rue de la Noë, 44321 Nantes Cedex 3, France
}

\begin{abstract}
Internal erosion (IE) of chemically reinforced granular materials results in dislodgement of particles from their rigid skeleton due to seepage stresses. Whether or not these particles can be dislodged and flushed out by seepage depends on (i) the amount of binding agent used to reinforce the granular matrix, (ii) the structure of pore network and (iii) severity of seepage stresses. Results of IE tests are presented for compacted-sand reinforced with increasing amounts of silica gel. The silica gel is a binding agent that permits low-permeability materials reinforcement. IE tests provided information about eroded particles, macro/ micro-structural changes and indicators of ongoing IE mechanisms. For instance, data highlighted the existence of up to three IE stages. This includes flushing of movable particles, binder removal and subsequent releases then self-filtering of fine particles within the rigid skeleton. From the careful monitorings of effluent particles (in terms of concentrations and sizes), it was possible to gauge the dynamics of binder removal. Besides, it was also possible to follow changes in dimensions of the smallest constriction that drives travel distances of dislodged particles.
\end{abstract}

\author{
Keywords: \\ Internal erosion \\ Reinforced granular material \\ Tests \\ Indicators \\ Constriction
}

\section{Introduction}

Erosion is ubiquitous in the natural and urban environments. Surface soils of the earth have been continuously changing as erosion sculpts the landscape. It reduces mountains to a fraction of their original size and carves out valleys and canyons between cliffs. Man-made infrastructures that support society, like dams or levees as well as agricultural lands also experience the processes of erosion and transport of detached material. For instance, in 2005 during Hurricane Katrina, the levee failures in New Orleans, USA, submerged $80 \%$ of the city causing death of $>1100$ inhabitants (Jonkman et al., 2009). The Federal studies that were initiated to provide answers about structures vulnerability stated that most levees sections that performed well were made of less erodible materials (Andersen et al., 2007; IPET, 2007).

Among all the erosion forms, internal erosion (IE) is especially dangerous since it is one of the most common causes of failure of embankment dams (Sherard et al., 1972a, 1972b; Arulanandan and Perry, 1983; Foster et al., 2000a, 2000b; Foster and Fell, 2001; Wan and Fell, 2002, 2004; Ronnqvist, 2005; Fell and Fry, 2007; Reiffsteck, 2007; Fox and Wilson, 2010). Four types of mechanisms have been identified in this context (Bonelli and Brivois, 2008): (i) development of defects in the primary fabric of large particles that support imposed stresses (like grain removal inducing stacks faults or dislocations), (ii) suffusion, which is the process whereby the fines fraction is entrained internally through the primary fabric of large particles, (iii) elongated cavities or channels that are eroded backward toward the reservoir, and (iv) contact erosion, which occurs at the interface between two solid domains of distinct granulometric distributions provided the coarse layer is not appropriate filter for finer layer. Actually, there may be no apparent geomorphic evidence, or only subtle evidence (such as minor cracks, slides, and depressions), that one or several IE processes are taking place. Moreover, a dam may breach within a few hours after evidence of the IE becomes obvious: as a spring discharging at the downstream toe of an embankment. Therefore, it is relevant to monitor changes in physical characteristics of the solid structure at an early stage of erosion. Variations of pore conditions (e.g. like the water content and permeability) and dynamics of particles fluidization (i.e. dislodgement then transport) are expected to trace the processes that control IE.

So far, research on the IE mainly focused on low cohesion or cohesionless granular materials like sand, gravels and diverse non-cohesive soils (US Army Corps of Engineers, 1953; Loebotsjkov, 1969; Arulanandan et al., 1980; Kovacs, 1981; Kenney and Lau, 1985; Burenkova, 1993; Reddi et al., 2000; Bendahmane et al., 2008). The data from the literature showed that the potential for instability of low cohesion/cohesionless materials depends on the ability of their small particles to be flushed throughout the 
constrictions of their pore network. However, unlike cohesionless granular materials, the reinforced granular materials are expected to endure seepage stresses even though their primary fabrics of particles prove to be unstable and/or their small particles in pores partially flushed out (Tam, 1996). Hence, granular material reinforcement has brought about a plethora of engineering applications: e.g. soil stabilization, slope protection, tunnels and underground excavations (Pitt et al., 2007). In this study, we performed IE tests on reinforced compacted-sand columns (CSCs) to probe the mechanisms inherent to IE in these particular granular materials. This paper, which is restricted to chemically reinforced CSCs, has three objectives. First, probing IE stages within CSCs reinforced with increasing amounts of stabilization agent. Second, the monitoring of particles released into the effluent with respect to their granulometry. Third, investigating the microstructural changes induced by seepage.

\section{Material and methods}

\subsection{Internal erosion experiments}

Three IE tests were performed at a constant inflow rate $\left(0.1 \mathrm{~L} \mathrm{~min}^{-1}\right.$, fluid velocities around $10^{-3} \mathrm{~m} \mathrm{~s}^{-1}$ ) from the bottom to the top of a transparent tube of height $0.1 \mathrm{~m}$ and $0.1 \mathrm{~m}$ in diameter filled with reinforced compacted Fontainebleau sand (Fig. 1). IE tests are different according to the reinforcement of the CSCs (i.e. amounts of binding agent). During every IE test, the weight of the CSC, the injection pressure $\left(P_{\mathrm{inj}}\right)$ and the granulometric distribution of eroded particles (from 0.01 to $100 \mu \mathrm{m}$ ) were measured at different time intervals. The experimental program also included a series of scanning electron microscope (SEM) micrographs.

\subsection{Sample preparation}

The Fontainebleau sand is a reference granular material that consists of sub-rounded grains with intermediate sphericity and a grain size range of $50-400 \mu \mathrm{m}$. Its particle and bulk densities are $\sim 2600 \mathrm{~kg} \mathrm{~m}^{-3}$ and $1500-1600 \mathrm{~kg} \mathrm{~m}^{-3}$, respectively, with an internal friction angle of $40-45^{\circ}$ and a cohesion of $70 \mathrm{~Pa}$ (van Mechelen, 2004). A colloidal dispersion of high molecular polysilicic acids was used to reinforce the sand matrix. Indeed, preliminary IE tests done on unreinforced Fontainebleau sand columns highlighted the prompt destabilization of their granular structure (see below). Due to its colloidal nature and its high water content ( $\sim 70 \%)$, the dispersion allows the reinforcement of low permeability materials $\left(<10^{-10} \mathrm{~m}^{2}\right)$. The colloids size lies between 5 and
$75 \mathrm{~nm}$ and the transformation of the colloidal silica dispersion into insoluble silica gel (i.e. the binder; $\sim 1300 \mathrm{~kg} \mathrm{~m}^{-3}$ particle density), upon addition of a saline solution, is irreversible. The gelation time was set to $\sim 1 \mathrm{~h}$. Once impregnated with the dispersion, and prior to gelation, sand compaction was achieved at the centimetric scale by using a dynamic impact method (load of $2.5 \mathrm{~N}$; height of $0.1 \mathrm{~m}$ ). Finally, prepared samples were kept at $20^{\circ} \mathrm{C}$ and $50 \%$ relative humidity for 1 week to gain strength and harden fully until IE tests. In the experiments, the amounts of colloidal silica dispersion were set for the silica gel to occupy $33 \%, 50 \%$ and $66 \%$ of the porosity of the compacted Fontainebleau sand $(n=0.38)$. We thus referred to the prepared CSCs as $\mathrm{N}_{33}, \mathrm{~N}_{50}$ and $\mathrm{N}_{66}$, respectively. The obtained $(n ; k)$ (as determined from the added amount of binder and water permeability measurements) for $\mathrm{N}_{33}, \mathrm{~N}_{50}$ and $\mathrm{N}_{66}$ equalled ( 0.25 ; $\left.10^{-13} \mathrm{~m}^{2}\right),\left(0.19 ; 5 \times 10^{-14} \mathrm{~m}^{2}\right)$ and $\left(0.13 ; 5 \times 10^{-15} \mathrm{~m}^{2}\right)$, respectively. The bulk density of the sand matrix was kept constant (close to $1600 \mathrm{~kg} \mathrm{~m}^{-3}$ ).

\subsection{Probing IE intensity}

To investigate the IE intensities, we monitored the evolutions of $P_{\mathrm{inj}}$, mass changes of CSCs during erosion tests and granulometric distributions of particles from the effluents (Fig. 1). $P_{\text {inj }}$ measuring system included a pressure transducer (Model 14 from AEP), which was used together with an automated data acquisition and processing software (WinATS 6.0 from Sysma ${ }^{\circledR}$ ). The interval of measurable relative pressure values was between $50 \mathrm{kPa}$ and $2000 \mathrm{kPa}$, and the accuracy of the measurements equalled $0.10 \%$. The pressure at the top of the CSCs was set equal to the standard atmosphere. The volumetric water content (i.e. $\theta$ ) was determined by monitoring the CSCs weights at a $0.1 \mathrm{~g}$ scale. $\theta$ accounts for two mechanisms: (i) the spreading of injected water within capillaries (i.e. this results in CSCs weights increase in the absence of notable particle releases) and (ii) the filling of newly formed pores (i.e. the evolution of CSCs weights is the net result of injected water and eroded material amounts). Hence, to adequately appraise the $\theta$ increases, volumes (resp. amounts) of $1-100 \mu \mathrm{m}$ eroded particles were repeatedly assessed using the granulometric distributions of effluent particles. Finally, coarse eroded particles were collected using a certified $100 \mu \mathrm{m}$ sieve placed above the lower effluent reservoir. Their mass was measured after drying at $90{ }^{\circ} \mathrm{C}$ for $24 \mathrm{~h}$ : the $>100 \mu \mathrm{m}$ particles primarily consisted of highly insoluble (silica gel coated) sand grains that exhibit limited wetting. This permitted to lower the drying temperature while keeping the data comparable. As a matter of fact, further drying at $110^{\circ} \mathrm{C}$ for $24 \mathrm{~h}$ did not result in significantly lower dry weights $(<0.5 \%)$.

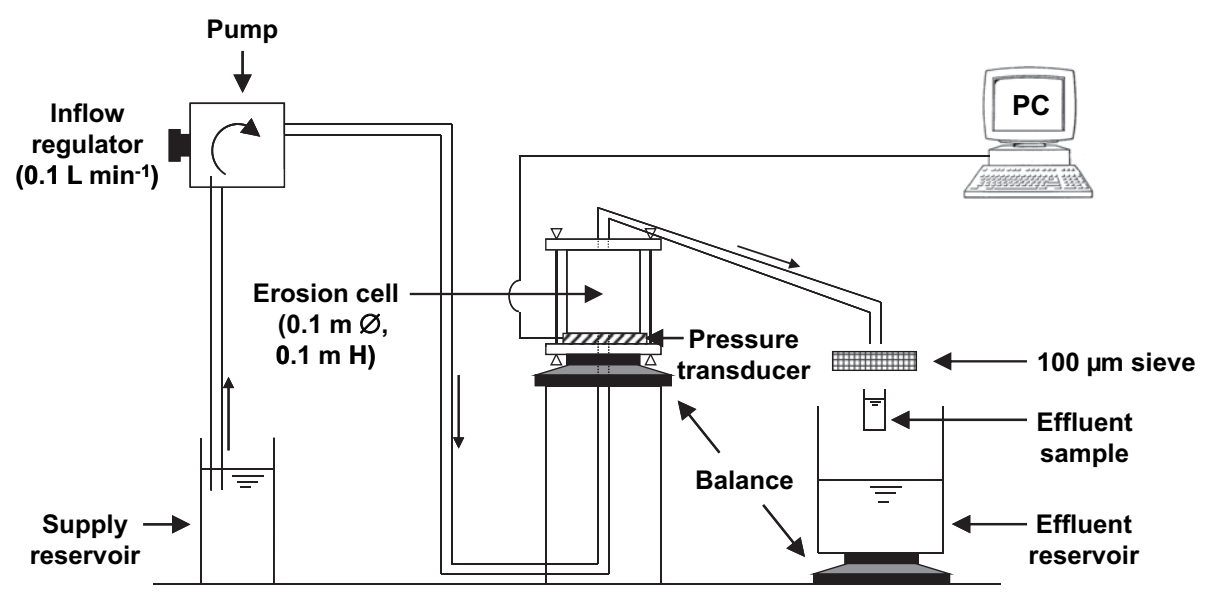

Fig. 1. Experimental set-up for internal erosion tests. 


\subsection{Characterisation of eroded CSCs and effluent particles}

In order to probe the effects of IE on the microstructure of CSCs, the sand skeleton and the binder of unexposed (i.e. preserved from IE) and eroded samples were examined by using a SEM device. Initially, unexposed and eroded samples were homogenously prepared by the same operator using analogous preparation and hardening methods. During IE tests, the unexposed samples were hermetically stored at $20^{\circ} \mathrm{C}$. Following IE tests, SEM micrographs were taken after carefully splitting the CSCs by hand. The granulometry of eroded particles was determined in the first few hours that followed the sampling of the effluents by means of two particle sizing systems (PSS) from CAD instrumentation. Size distributions (volume based) of small eroded particles from 1 to $100 \mu \mathrm{m}$ diameter range were determined by single-particle optical sensing using an AccuSizer ${ }^{\text {TM }} 780$ optical PSS. These correspond to the finest fraction of Fontainebleau sand ( $<5 \%$ in mass) and coarse silica gel particles from the binder. At the nanometric scale, size distributions (volume based) of eroded nanoparticles ranging from 0.01 to $1 \mu \mathrm{m}$ were assessed by dynamic light scattering using a submicrometric Nicomp ${ }^{\mathrm{TM}} 380$ PSS. These correspond to the silica gel colloids from the binder. The accuracy of (sub)micrometric particles sizing systems was less that $1 \%$. Data were corrected using the granulometry of particles initially present in the injected water as a blank.

\section{Results and discussion}

In advance of the IE tests on reinforced CSCs, we investigated how Fontainebleau sand columns without the chemical reinforcement resist against seepage force. The granular structure of the unreinforced Fontainebleau sand columns was promptly destabilized by the eroding fluid passing through them in less than a few seconds. Beyond $1 \mathrm{~min}$ of water injection, the cohesion between sand grains disappeared and notable amounts of sand were discharged. The observed mechanism was not IE but overall transport of fluidized sand grains such as sand boiling.

\subsection{The three stages of internal erosion}

Fig. 2A-C shows the evolutions of masses of $\mathrm{N}_{33}, \mathrm{~N}_{50}$ and $\mathrm{N}_{66}$ CSCs during IE tests, respectively. $t=0 \mathrm{~s}$ denotes the outflowing of the effluent. Mass evolution curves developed up to three zones: an early mass intake zone, which increases with the amount of binder $\left\{\right.$ at $t=(0-85) \times 10^{3} \mathrm{~s}$ for $\mathrm{N}_{50}$ and $(0-30) \times 10^{3} \mathrm{~s}$ for $\left.\mathrm{N}_{66}\right\}$, a later zone of plateau at $t=(0-1) \times 10^{3},(85-130) \times 10^{3}$ and
$(30-50) \times 10^{3}$ s for $\mathrm{N}_{33}, \mathrm{~N}_{50}$ and $\mathrm{N}_{66}$, respectively \} and a final mass loss zone. This observation is consistent with the initiation (loss of the impervious function), continuation (creation of pathways for eroding fluid) and progression (destabilization of the granular structure) phases described by Foster and Fell (2001) for embankment dam filters. The mass intake, which is observable only for $\mathrm{N}_{50}$ and $\mathrm{N}_{66}$ \{average $\pm \mathrm{SD} ;(5 \pm 2) \times 10^{-7}$ and $(29 \pm 18) \times 10^{-7} \mathrm{~kg} \mathrm{~s}^{-1}$, respectively\}, proves the lasting infiltration of the injected water into the pore network. The plateau zone is developed particularly in $\mathrm{N}_{50}$ (duration of $45 \times 10^{3} \mathrm{~s}$ ) and to a lesser extent in $\mathrm{N}_{66}$ and $\mathrm{N}_{33}\left(20 \times 10^{3}\right.$ and $1000 \mathrm{~s}$, respectively). It supports the existence of an IE episode during which both mass intake via water infiltration and flushing of eroded particles by seepage were low or balanced each other out. In the last zone, the masses of the reinforced CSCs decreased slower with increasing amounts of binder: $(8.3 \pm 1.1) \times 10^{-7},(0.8 \pm 0.1) \times 10^{-7}$ and $(0.4 \pm 0.2) \times 10^{-7} \mathrm{~kg} \mathrm{~s}^{-1}$ for $\mathrm{N}_{33}, \mathrm{~N}_{50}$ and $\mathrm{N}_{66}$, respectively.

Fig. $3 \mathrm{~A}$ and $\mathrm{B}$ display the evolutions of eroded volumes of 1-100 $\mu \mathrm{m}$ particles (as determined from the granulometry of effluent particles) and $\theta$, respectively. $\theta$ of $\mathrm{N}_{33}, \mathrm{~N}_{50}$ and $\mathrm{N}_{66}$ CSCs exhibited analogous trends (Fig. 3B): (i) an initial period of rapid linear increase $\left\{(12.3 \pm 1.5,5.6 \pm 0.4\right.$ and $45 \pm 7) \times 10^{-7} \mathrm{~s}^{-1}$, respectively $\}$, which except for $\mathrm{N}_{33}\left\{(0-10.8) \times 10^{3} \mathrm{~s}\right\}$ corresponds to the mass intake zone and (ii) a later period of slower increase $\{(6.0 \pm 0.7$, $0.8 \pm 0.1$ and $0.4 \pm 0.3) \times 10^{-7} \mathrm{~s}^{-1}$, respectively $\}$ in the plateau and mass loss zones at $(10-61) \times 10^{3} \mathrm{~s}_{\text {for }} \mathrm{N}_{33},(85-250) \times 10^{3} \mathrm{~s}$ for $\mathrm{N}_{50}$ and $(30-250) \times 10^{3} \mathrm{~s}$ for $\mathrm{N}_{66}$ \}. The rapid initial increase of $\theta$ accounts for the filling of accessible pores with injected water and, as the volumes of $1-100 \mu \mathrm{m}$ eroded particles indicate $\left\{(32.2 \pm 0.3,0.8 \pm 0.1\right.$ and $0.4 \pm 0.1) \times 10^{-10} \mathrm{~m}^{3} \mathrm{~s}^{-1}$, respectively $\}$ (Fig. 3A), the flushing out of most movable particles (like loose and/or small particles that can easily exit the material). By comparison, in the plateau and mass loss zones, the slower increases of $\theta$ likely account for slower filling of the less accessible pores and lower effluent loading with $1-100 \mu \mathrm{m}$ particles $\{(1.4 \pm 0.1$, $0.3 \pm 0.1$ and $0.2 \pm 0.1) \times 10^{-10} \mathrm{~m}^{3} \mathrm{~s}^{-1}$, respectively $\}$ and rigid skeleton constitutants.

During all the IE tests, head losses between the bottom and top of the CSCs markedly decreased ( $\Delta P$ of 10,107 and $506 \mathrm{kPa}$, respectively) (Fig. 3C). This resulted in significant $k$ increases $\left(k: k_{0}\right.$ ratio values reached up to 40, 28 and 9, respectively) (Fig. 3D). Assuming that infiltration of injected water and removal of silica gel lead to local drain of the finest sand grains and further destabilization of CSCs structures, we used exponential regression models to fit $P_{\text {inj }}$ and $k$ evolutions: $P_{\text {inj }}(\mathrm{Pa})=3 \times 10^{7} \mathrm{e}^{-3 \theta}\left(\mathrm{r}^{2}\right.$, squared Pearson's correlation coefficient $=0.87)$ and $k\left(\mathrm{~m}^{2}\right)=6 \times 10^{-16} \mathrm{e}^{30 \theta}\left(r^{2}=0.81\right)(p$, value used to reject null hypothesis $=0.05)$. Since the intrinsic
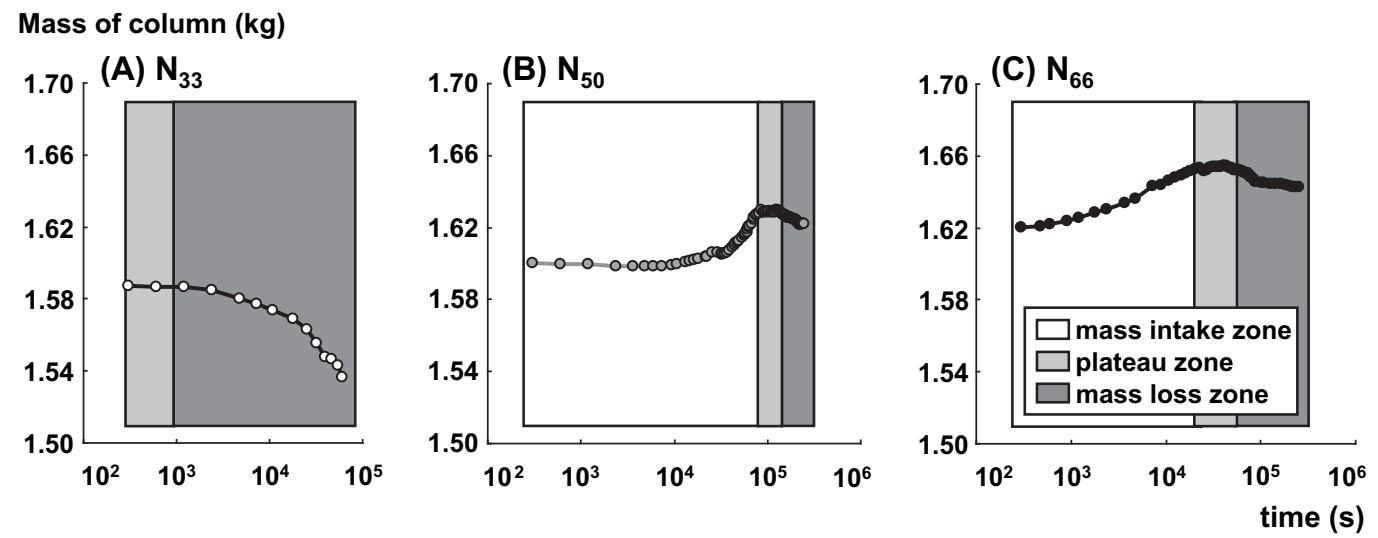

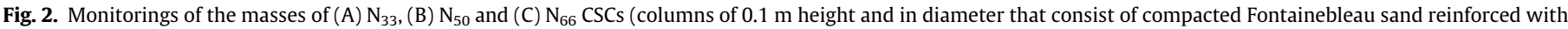
increasing amounts of silica gel) during IE tests. Water inflow is set constant and equalled $0.1 \mathrm{~L} \mathrm{~min}^{-1}$ (time $=0 \mathrm{~s}$ denotes the outflowing of the effluent). 

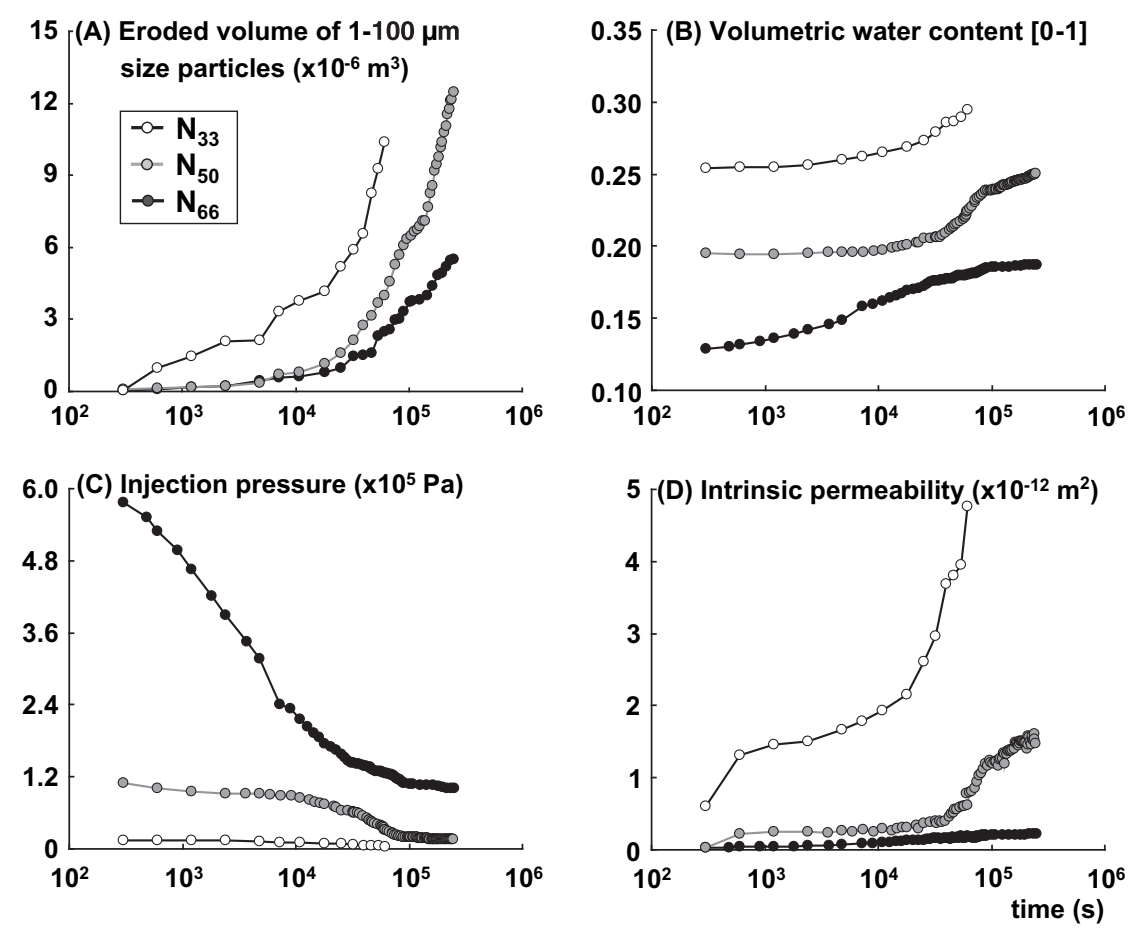

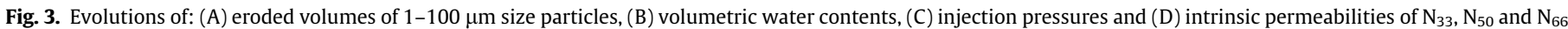
eroded CSCs, respectively.

permeability depends on the geometry of constrictions and interconnections between pores, the obtained relationships suggest that the filling of pores and subsequent drain of fluidized particles could have initiated developments (either in terms of sizes or quantities) of channels and/or capillaries for water flowing throughout the material.

\subsection{The finest Fontainebleau sand grains}

Fig. 4A-C shows the contributions of micrometric particles to instantaneous discharged mass of solids for IE tests with $\mathrm{N}_{33}, \mathrm{~N}_{50}$ and $\mathrm{N}_{66}$ CSCs, respectively. They gather eroded silica gel particles $(1-50 \mu \mathrm{m}$, average diameter $11 \pm 5 \mu \mathrm{m})$ and finest Fontainebleau sand grains (50-100 $\mu \mathrm{m}$, average diameter $65 \pm 7 \mu \mathrm{m}$ ) that are easily flushed out by seepage. Put succinctly, obtained results prove the continuous erosion of the binder (darkest areas below $50 \mu \mathrm{m}$ ), which implies an increasing risk of CSCs failure due to the removal of finest Fontainebleau sand grains and the subsequent instability of coarse sand grains that support imposed stresses.

In the mass intake zone, effluent concentrations of $50-100 \mu \mathrm{m}$ Fontainebleau sand grains underwent fast decreases $\{(150 \pm 20$, $66 \pm 5$ and $42 \pm 2) \times 10^{-6} \mathrm{~kg} \mathrm{~m}^{-3} \mathrm{~s}^{-1}$ for $\mathrm{N}_{33}, \mathrm{~N}_{50}$ and $\mathrm{N}_{66}$, respectively and reached minimal values (all around $0.02 \mathrm{~kg} \mathrm{~m}^{-3}$ ) as soon as $t=1000 \mathrm{~s}$. The corresponding mass losses were $(0.42 \pm$ $0.07) \times 10^{-3},(0.19 \pm 0.02) \times 10^{-3}$ and $(0.15 \pm 0.01) \times 10^{-3} \mathrm{~kg}$ : i.e. $0.66 \pm 0.14 \%, 0.30 \pm 0.06 \%$ and $0.24 \pm 0.02 \%$ of the amount of fines used for every single CSC preparation. The monitoring of effluent loading with $50-100 \mu \mathrm{m}$ Fontainebleau sand grains provides useful information about IE dynamics and the transport of fluidized particles into the CSCs. For instance, as previous results indicated, most of fines are initially immobilized in closed pore spaces or cavities ( $>99 \%$ of CSCs' proportions). Hence, the swift releases of $50-100 \mu \mathrm{m}$ Fontainebleau sand grains that occur during the plateau and mass loss zones can be considered as indicators of the progressive deterioration of CSCs structure (like the expanding of constrictions and/or interconnecting pores). Releases of fines are particularly visible in Fig. $4 \mathrm{~A}\left(\mathrm{~N}_{33}\right.$ at $\left.t>35 \times 10^{3} \mathrm{~s}\right)$ and $\mathrm{B}\left(\mathrm{N}_{50}\right.$ at $t=170 \times 10^{3} \mathrm{~s}$ ), while $\mathrm{N}_{66}$, with its high binder content, displayed lowest contributions of $50-100 \mu \mathrm{m}$ Fontainebleau sand grains (Fig. 4C). It may be concluded that, in regard to IE in chemically reinforced CSCs, the important criterion is not so much the movable sand grains contents but, rather, the suddenness of their mobilisation.

\subsection{The silica gel particles}

From an engineering point of view, delayed occurrence of 50-100 $\mu \mathrm{m}$ Fontainebleau sand grains into the effluent is a consequence of IE mechanisms that affect the binder (e.g. fracture and removal of the intergranular silica gel). Actually, silica gel particles constituted, either in terms of volume $(70 \pm 8 \%, 79 \pm 8 \%$ and $73 \pm 15 \%$, respectively) or mass ( $54 \pm 10 \%, 67 \pm 11 \%$ and $65 \pm 19 \%$, respectively), most of the $1-100 \mu \mathrm{m}$ eroded particles. It is thus pertinent to monitor their removal dynamics by injected water (fractions $1-50 \mu \mathrm{m}$ in Fig. $4 \mathrm{~A}-\mathrm{C}$ ).

In the first $1200 \mathrm{~s}$ of the tests, unlike the $50-100 \mu \mathrm{m}$ Fontainebleau sand grains, the effluent concentrations of silica gel particles underwent their sharpest decreases for the CSCs with the highest binder contents: $(130 \pm 20,220 \pm 10$ and $260 \pm 30)$ $\times 10^{-6} \mathrm{~kg} \mathrm{~m}^{-3} \mathrm{~s}^{-1}$ for $\mathrm{N}_{33}, \mathrm{~N}_{50}$ and $\mathrm{N}_{66}$, respectively. This induces losses of $3.3 \pm 0.2 \%, 2.7 \pm 0.1 \%$ and $2.4 \pm 0.3 \%$ of the amount of binder used for every individual CSC preparation. According to Kenney et al. (1985), the size of the predominant constrictions in a void network of a filter is approximately equal to one-quarter the size of the particles making the filter; here $\sim 220 / 4 \mu \mathrm{m}$. This means that the eroded silica gel particles (average diameter of $11 \pm 5 \mu \mathrm{m}$ ) may even pass through the constrictions formed by the finest Fontainebleau sand grains (average diameter of $65 \pm 7 \mu \mathrm{m}$ ). Since most of the movable silica gel particles ignore the filtration mechanisms, the strong concentration decreases observed in most reinforced CSCs primarily reflect the lower 

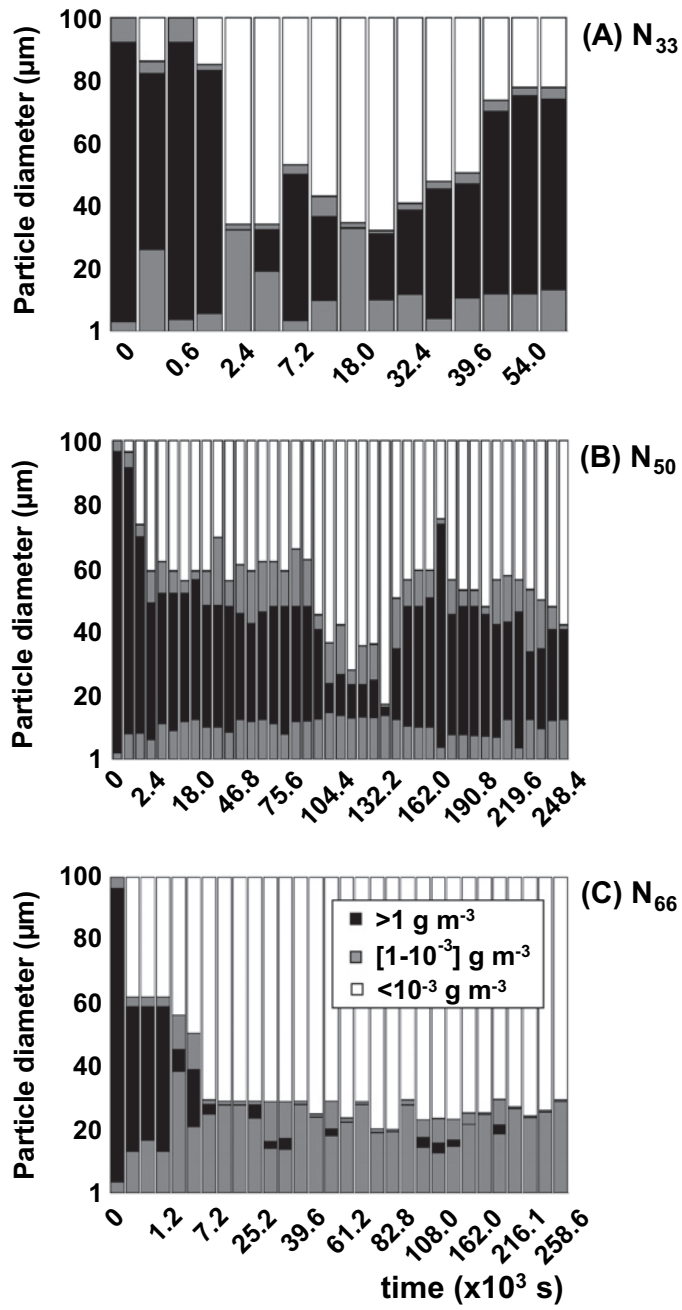

Fig. 4. Contributions of micrometric particles (finest Fontainebleau sand grains + eroded silica gel particles) to the instantaneous discharged mass of solids for IE tests with (A) $\mathrm{N}_{33}$, (B) $\mathrm{N}_{50}$ and (C) $\mathrm{N}_{66}$ CSCs, respectively.

erodibility of their binder (mass effect). Another observation is that minima of concentration accompanied the developments of plateau or mass loss zones: at $(2-25) \times 10^{3} \mathrm{~s}$ in $\mathrm{N}_{33}$,
$(95-130) \times 10^{3} \mathrm{~s}$ in $\mathrm{N}_{50}$ and around $30 \times 10^{3} \mathrm{~s}$ in $\mathrm{N}_{66}$. This means that silica gel fragments are then hardly dislodged from the binder $\left\{(0.5 \pm 0.1,0.2 \pm 0.1\right.$ and $0.3 \pm 0.1) \times 10^{-7} \mathrm{~kg} \mathrm{~s}^{-1}$ for $\mathrm{N}_{33}, \mathrm{~N}_{50}$ and $\mathrm{N}_{66}$, respectively\} and, as a result, the rigid skeleton would effectively resist the seepage stresses. With increasing IE time, however, the effluent silica gel particles concentrations tended to increase either gradually $\left\{(0.5 \pm 0.1) \times 10^{-6} \mathrm{~kg} \mathrm{~m}^{-3} \mathrm{~s}^{-1}\right.$ for $\left.\mathrm{N}_{33}\right\}$ or as peaks (up to 0.91 and $0.32 \mathrm{~kg} \mathrm{~m}^{-3}$ for $\mathrm{N}_{50}$ and $\mathrm{N}_{66}$, respectively), which matched reasonably well with the swift releases of fine Fontainebleau sand grains $\left\{p=0.05, r^{2}=0.66 ;[\text { sand }]_{50-100 \mu m}=0.34\right.$ [binder $\left.]_{1-50 \mu \mathrm{m}}\right\}$. It implies that beyond the period of low effluent loading with silica gel particles, instability of CSCs can be gauged using the occurrences of fine sand grains as indicators of IE of remaining binder.

\subsection{The dynamics of particle transport within CSCS}

Fig. 5A-C display the diameters of effluents' (i) smallest nanometric particles (SNP; right scale) and (ii) largest micrometric particles (LMP; left scale) that are strongly flushed out by seepage $\left(>10^{-3} \mathrm{~kg} \mathrm{~m}^{-3}\right)$. First, silica gel is practically insoluble $(<100 \mathrm{nmol}$ $\mathrm{L}^{-1}$ at $\mathrm{pH} 7-8$; Iler, 1979) and thus SNP depict the finest silica colloids from the binder that can be mechanically dislodged by seepage. We thus assumed that SNP sizes should be proportionate with seepage stresses: i.e. coarser silica colloids would be dislodged at higher shear forces acting on the binder. Second, if sizes of eroded micrometric particles are smaller than CSCs' constrictions, they can be moved by water flow through the pore network until they are discharged into the effluent. We therefore assumed that LMP diameters provide some measure of the dimensions of the smallest constriction that permit their passage.

From LMP data, the minimal constrictions are largest in the very beginning of IE tests ( $80-100 \mu \mathrm{m}$, left scale). This is about twice the value obtained using Kenney's formulation $(\sim 55 \mu \mathrm{m}$, see Section 3.3), likely due to the preferential leaching of most superficial, thus unfiltered, sand grains. In fact, except for $\mathrm{N}_{33}$, which does not exhibit an initial mass intake zone, sizes of the minimal constrictions rapidly tend to stabilize around $50-60 \mu \mathrm{m}(49 \pm 3$ and $59 \pm 1 \mu \mathrm{m}$ for $\mathrm{N}_{50}$ and $\mathrm{N}_{66}$, respectively). Later at $t=(0.3-1.2,30-90$ and 2.4-18) $\times 10^{3} \mathrm{~s}$ for $\mathrm{N}_{33}, \mathrm{~N}_{50}$ and $\mathrm{N}_{66}$, respectively\}, marked size increases of the effluents' SNP either precede or accompany additional narrowing of constrictions (resp. down to 32,17 and $16 \mu \mathrm{m}$ ). This suggests that, previously to the plateau zone, shear forces that affect the binder would produce sufficiently large
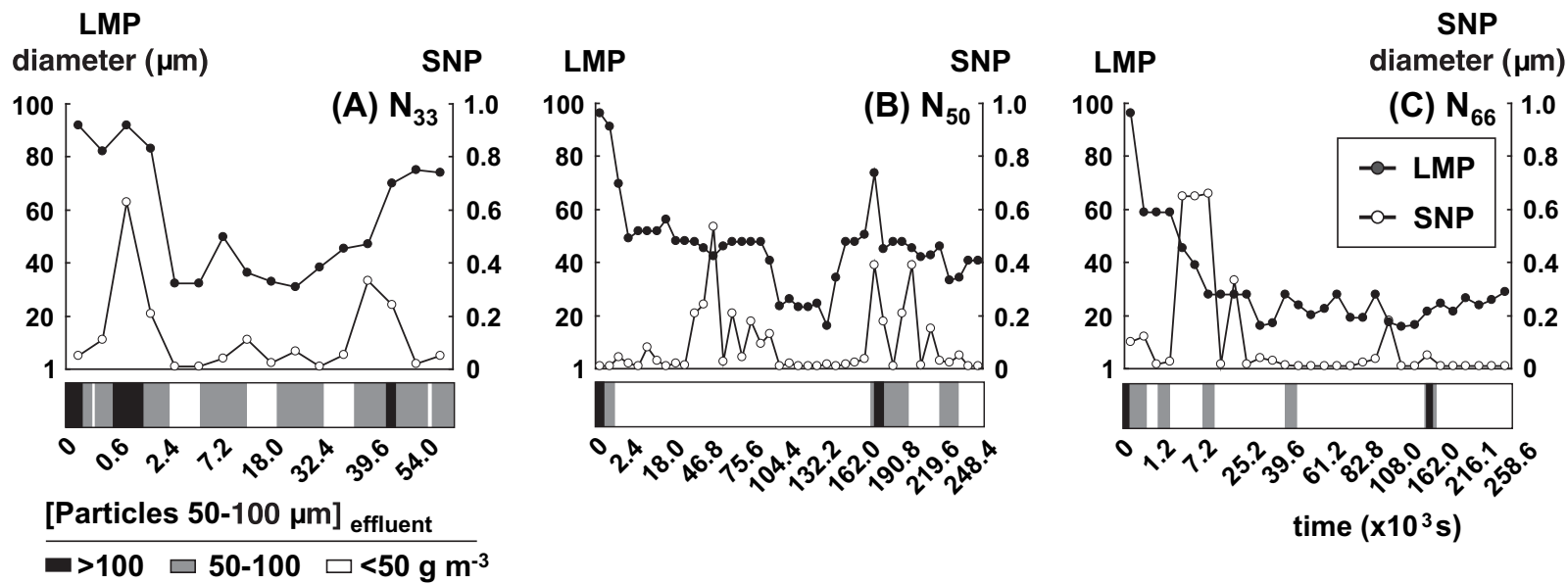

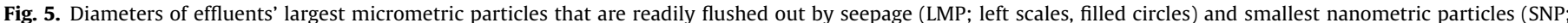

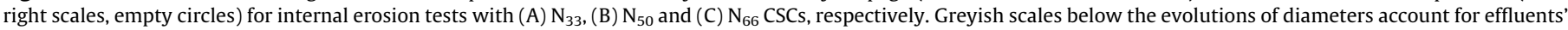
concentrations of 50-100 $\mu \mathrm{m}$ size Fontainebleau sand grains (in $\mathrm{g} \mathrm{m}^{-3}$ ). 

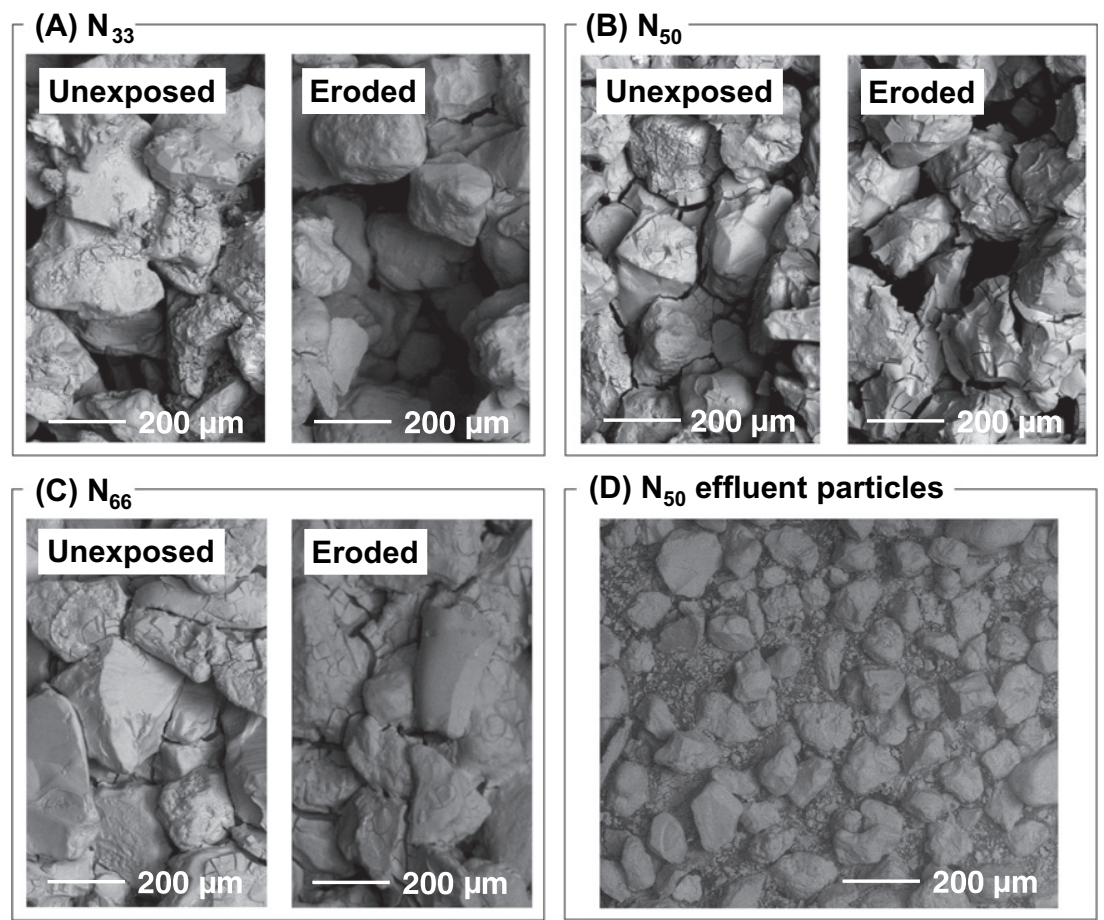

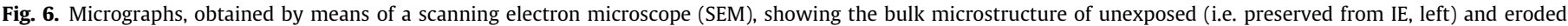
(right) (A) $\mathrm{N}_{33}$, (B) $\mathrm{N}_{50}$ and (C) $\mathrm{N}_{66}$ CSCs, respectively and (D) displays the particles discharged from $\mathrm{N}_{50}$ CSC during a swift release of fine Fontainebleau sand grains.

particles in the pore network (via the dislodgement of coarse silica gel fragments and/or sand grains) to partially obstruct the existing constrictions. This is further confirmed by concomitant decreases in slope values of $\theta$ and thereafter $k$ curves (see Section 3.1 and Fig. 3B and D). Based on the previous remarks and measured IE rates, the plateau zone not only depicts a domain of lower erodibility of binder but also of hindered transport of dislodged fine $(50-100 \mu \mathrm{m})$ Fontainebleau sand grains. Finally, in the mass loss zone, peaks of SNP match to broadenings (resp. higher effluent concentrations of $50-100 \mu \mathrm{m}$ size grains) \{at $t=(7.2-10.8$ and $40-47) \times 10^{3} \mathrm{~s}$ for $\mathrm{N}_{33}$, $(169-176$ and 212$) \times 10^{3} \mathrm{~s}$ for $\mathrm{N}_{50}$ and $144 \times 10^{3} \mathrm{~s}$ for $\mathrm{N}_{66}$ ) or narrowings (resp. lower effluent concentrations of $50-100 \mu \mathrm{m}$ size grains) \{at $\mathrm{t}=25 \times 10^{3} \mathrm{~s}$ for $\mathrm{N}_{33}$, (198 and 234) $\times 10^{3} \mathrm{~s}$ for $\mathrm{N}_{50}$ and $102 \times 10^{3} \mathrm{~s}$ for $\mathrm{N}_{66}$ \} of constrictions (greyish scales in Fig. 5A-C). This demonstrates that recorded mass losses are the sum of dynamic releases and filterings of eroded fine sand grains.

\subsection{The microstructural changes}

Fig. 6A-C displays the bulk microstructure of unexposed and eroded $\mathrm{N}_{33}, \mathrm{~N}_{50}$ and $\mathrm{N}_{66}$ CSCs, respectively. The micrographs clearly show that, in spite of the microstructural changes inherent to SEM analyses (like the shrinkage of the binder), silica gel within eroded samples is more fractured and in part removed. As a matter of fact, micrographs of effluent particles exhibit multiple silica gel particles ranging from $<1$ to $50 \mu \mathrm{m}$ (Fig. 6D). The extent of silica gel/sand grains removal (as estimated using the surface increase of the darkest areas) averages $12 \pm 3 \%, 6 \pm 1 \%$ and $4 \pm 2 \%$ for $\mathrm{N}_{33}$, $\mathrm{N}_{50}$ and $\mathrm{N}_{66}$, respectively. These exceed by up to an order of magnitude the values obtained using the total weight of $>100 \mu \mathrm{m}$ eroded grains $(5.2 \pm 0.1 \%, 0.6 \pm 0.2 \%$ and $0.5 \pm 0.1 \%$, respectively): i.e. $50-90 \%$ of eroded particles are smaller than $100 \mu \mathrm{m}$ and their contribution increases with the amount of binder. For instance, size ranges of apparent voids formed during IE are 25-500, 15-300 and 5-250 $\mu \mathrm{m}$ for $\mathrm{N}_{33}, \mathrm{~N}_{50}$ and $\mathrm{N}_{66}$, respectively. Lowest values are consistent with dimensions of the smallest constriction based on the granulometry of effluent particles (see Section 3.4) whereas the highest values match the maximal size of effluent particles (e.g. up to $300 \mu \mathrm{m}$ for $\mathrm{N}_{50}$ at $\mathrm{t}=170 \times 10^{3} \mathrm{~s}$ during a swift release of fine Fontainebleau sand grains, Fig. 6D).

\subsection{Data synthesis}

At a constant inflow rate, seepage tests on chemically reinforced CSCs highlight the existence of up to three IE stages: (i) an early CSCs mass intake stage, which corresponds to the filling of accessible pores with injected water and flushing of most movable particles, (ii) a subsequent stage of low binder erodibility coupled with the clogging of constrictions, and (iii) a later CSCs mass loss stage of dynamic releases and self-filtering of sand grains from/within the rigid skeleton.

From a macroscopic point of view, the concomitant increases of $\theta$ and $k$ indicate the development of channels and/or capillaries for the injected water. The dynamics of channels developments depend on the size of constrictions and IE stages: (i) it rapidly increases during the mass intake stage, (ii) decelerates because of material acting as a filter and in part retains dislodged particles during the low binder erodibility stage, and (iii) fluctuates according to releases and filtration of sand grains during the mass loss stage.

Microstructural changes firstly consist of the hydraulic fracturing of the binder. Binder deterioration significantly increases while lowering the amount of binder used for CSCs preparation (mass effect). Continuous drain of silica gel fragments and the dislodgement of fine Fontainebleau sand grains forms voids within the primary fabric that incurs shear stresses. Sizes of the largest voids are consistent with that of coarsest particles discharged during the swift sand grains releases. In turn, the destabilization of CSCs structures provides favourable conditions for further binder removal. 


\section{Acknowledgements}

This research was financially supported by French National Project Erinoh Project (Axis D: durability of injected soils). The authors would like to thank L.H. Tung for his contribution to experimental tests. The authors gratefully acknowledge Y. Benoit for providing the scanning electron microscope micrographs. This manuscript benefited from thorough reviews by two anonymous reviewers and T. Kozaki.

\section{References}

Andersen, C.F., Battjes, J.A., Daniel, D.E., Edge, B., Espey, W., Gilbert, R.B., Jackson, T.L., Kennedy, D., Mileti, D.S., Mitchell, J.K., Nicholson, P., Pugh, C.A., Tamaro, G., Traver, R., Buhrman, J., Dinges, C.V., Durrant, J.E., Howell, J., Roth, L.H., 2007. The New Orleans hurricane protection system: what went wrong and why. A Report by the American Society of Civil Engineers, Washington, D.C.

Arulanandan, K., Gillogley, E., Tully, R., 1980. Development of a quantitative method to predict critical shear stress and rate of erosion of natural undisturbed cohesive soils. Technical report of the US Army Waterways Experiment Station GL-80-5, Washington, DC.

Arulanandan, K., Perry, E.B., 1983. Erosion in relation to filter design criteria in earth dams. J. Geotech. Eng. 109, 682-698.

Bendahmane, F., Marot, D., Alexis, A., 2008. Experimental parametric study of suffusion and backward erosion. J. Geotech. Geoenviron. Eng. 134, 57-67.

Bonelli, S., Brivois, O., 2008. The scaling law in the hole erosion test with a constant pressure drop. Int. J. Numer. Anal. Meth Geomech. 32, 1573-1595.

Burenkova, V.V., 1993. Assessment of suffusion in non-cohesive and graded soils. In: Brauns, Heibum, Schuler, (Eds.), Proceedings, the First International Conference "Geo-Filters", Karlsruhe, Germany, 20-22 October 1992, Filters in Geotechnical Engineering, Balkema, 357-360.

Fell, R., Fry, J.-J., 2007. In: Taylor, R., Francis, W. (Eds.), Internal Erosion of Dams and their Foundations. London.

Foster, M., Fell, R., Spannagle, M., 2000a. Statistics of embankment dam failures and accidents. Can. Geotech. J. 37, 1000-1024.

Foster, M., Fell, R., Spannagle, M., 2000b. Method for assessing the relative likelihood of failure of embankment dams by piping. Can. Geotech. J. 37, 1025-1061.

Foster, M.A., Fell, R., 2001. Assessing Embankment Dam Filters that do not satisfy Design Criteria. J. Geotech. Geoenviron. Eng. 127, 398-407.

Fox, G.A., Wilson, G.V., 2010. The role of Subsurface flow in hillslope and stream bank erosion: a review. Soil Sci. Soc. Am. J. 74, 717-733.

Iler, R.K., 1979. In: Wiley J. (Ed.), The Chemistry of Silica: Solubility, Polymerization, Colloid and Surface Properties and Biochemistry of Silica. New York.
IPET (Interagency Performance Evaluation Task Force), 2007. Performance Evaluation of the New Orleans and Southeast Louisiana Hurricane Protection System. Final Report of the US Army Corps of Engineers, vol III. The Hurricane Protection System. <https://ipet.wes.army.mil/>.

Jonkman, S.N., Maaskant, B. Boyd, E., Levitan, M.L., 2009. Loss of life caused by the flooding of New Orleans after hurricane katrina: analysis of the relationship between flood characteristics and mortality. Risk Anal. 29, 676-698.

Kenney, T.C., Chahal, R., Chiu, E., Ofoegbu, G.I., Omange, G.N., Ume, C.A., 1985 Controlling constriction sizes of granular filters. Can. Geotech. J. 22, 32-43.

Kenney, T.C., Lau, D., 1985. Internal stability of granular filters. Can. Geotech. J. 22 215-225.

Kovacs, G., 1981. Seepage Hydraulics. Elsevier Scientific, Amsterdam, The Netherlands.

Loebotsjkov, E.A., 1969. The calculation of suffusion properties of nocohesive soils when using non-suffusion analog (in Russia). Publication of the technical university of Brno, Svazek, Czechoslovakia, pp. 135-148.

Pitt, R., Lake, D., Clark, S., 2007. Construction Site Erosion and Sediment Controls: Planning, Design, and Performance. DEStech publications Inc., Lancaster Pennsylvania, USA

Reddi, L.N., Lee, I.M., Bonala, M.V.S., 2000. Comparison of internal and surface erosion using flow pump tests on a sand-kaolinite mixture. Geotech. Test. J. 23 $116-122$.

Reiffsteck, P., 2007. Evaluation of erosion of soil used in dykes and earth embankments which are subjected to flood. In: Fell, R., Fry, J.-J. (Eds.), Internal Erosion of Dams and Their Foundations. Balkema, 191-202.

Ronnqvist, H., 2005. Evaluating internal instability and internal erosion in selection of existing Swedish embankment dams. In: Fell, R., Fry, J.-J. (Eds.), Internal Erosion of Dams and Their Foundations. Balkema, 203-207.

Sherard, J.L., Decker, R.S., Ryker, N.L., 1972a. Piping in earth dams of dispersive clay. Proceedings of ASCE Specialty Conference on the Performance of Earth and Earth Supported Structures, Purdue University, West Lafayette IN, 589-626.

Sherard, J.L., Decker, R.S., Ryker, N.L., 1972b. Hydraulic fracturing in low dams of dispersive clay. Proceedings of ASCE Specialty Conference on the Performance of Earth and Earth Supported Structures, Purdue University, West Lafayette IN $653-689$

Tam, J.G., 1996. Grout expectations. Description of and applications for grouts used in the civil engineering field. Unpublished Report. 22 pp. <http:// www.ocf.berkeley.edu/ tamjo/grout/Grout-rep.html> (01.03.11).

US Army Corps of Engineers, 1953. Filter experiments and design criteria. Technical memorandum of the US Army Waterways Experiment Station No. 3-360, Vicksburg.

van Mechelen, J.L.M., 2004. Strength of moist sand controlled by surface tension for tectonic analogue modelling. Tectonophysics 384, 275-284.

Wan, C.F., Fell, R., 2002. Investigation of internal erosion and piping of soils in embankment dams by the slot erosion test and the hole erosion test. UNICIV Report: No. R-412. The University of New South Wales, Sydney, Australia.

Wan, C.F., Fell, R., 2004. Investigation of rate of erosion of soils in embankment dams. J. Geotech. Geoenviron. Eng. 130, 373-380. 